\title{
Borowetan Sebuah Situs Di Wilayah Kerakaian Balitung
}

\section{Baskoro Daru Tjahjono}

Keywords: hindu-buddha, kingdom, spatial, inscription, brick structure

\section{How to Cite:}

Tjahjono, B. D. (2005). Borowetan Sebuah Situs Di Wilayah Kerakaian Balitung. Berkala Arkeologi, 25(1), 1-7. https://doi.org/10.30883/jba.v25i1.904

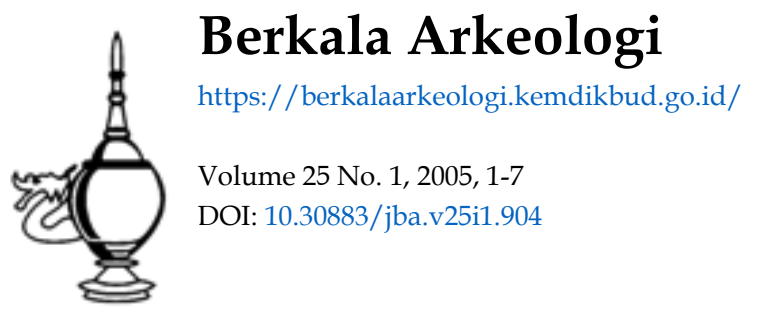

\section{c) (1) (5)}

This work is licensed under a Creative Commons Attribution-NonCommercial-ShareAlike 4.0 International License. 


\title{
BOROWETAN SEBUAH SITUS \\ DI WILAYAH KERAKAIAN BALITUNG
}

\author{
Oleh : Baskoro Daru Tjahjono
}

\section{Situs Borowetan}

Borowetan adalah sebuah situs baru yang ditemukan di Desa Borowetan, Kecamatan Banyuurip, Kabupaten Purworeja oleh warga setempat pada bulan Mei tahun 2004. Secara astronomis lokasi situs berada pada koordinat $110^{\circ} 00^{\prime}$ $37,7^{\prime \prime}$ BT dan $7^{\circ} 45^{\prime} 06^{\prime \prime}$ LS. Desa Borowetan berjarak $3 \mathrm{~km}$ di sebelah selatan kota Purworeja. Tinggalan arkeologis di Situs Borowetan berupa struktur bata kuna. Struktur bata tersebut berada di tepi sungai kecil yang merupakan saluran irigasi dari Sungai Beji, ditemukan pada kedalaman $120 \mathrm{~cm}$ dari permukaan tanah. Struktur bata yang tampak di permukaan tanah adalah bagian sisi timur dan sudut tenggara dari sebuah bangunan yang belum diketahui bentuk dan fungsinya. Panjang struktur bata yang tampak dipermukaan tanah $3,5 \mathrm{~m}$. Ukuran bata bervariasi, rata-rata mempunyai panjang $30-31 \mathrm{~cm}$, lebar $18-19 \mathrm{~cm}$, dan tebal $8-9$ $\mathrm{cm}$. Lokasi temuan berada di tanah pekarangan Djojo Sukarto. Tidak jauh dari lokasi itu, yaitu kira-kira $200 \mathrm{~m}$ di sebelah barat situs ditemukan sebuah lumpang batu dan lebih ke barat lagi kira-kira $400 \mathrm{~m}$ adalah lokasi temuan prasasti Kayu Ara Hiwang.

Temuan situs tersebut telah dilaporkan kepada Dinas Kebudayaan dan Pariwisata Kabupaten Purworejo, yang kemudian dilimpahkan kepada Balai Arkeologi Yogyakarta untuk melakukan penelitian. Menindaklanjuti surat Kepala Dinas Kebudayaan dan Pariwisata Kabupaten Purworejo tersebut, kemudian dilakukan penelitian kepurbakalaan oleh tim dari Balai Arkeologi Yogyakarta. Adapun tujuan dari penelitian tersebut adalah untuk mengidentifikasi situs, temuan struktur bata, dan lingkungan sekitar situs guna mengetahui potensi tinggalan arkeologisnya, serta untuk menentukan langkah-langkah penanganan selanjutnya. Sedangkan metode penelitian menggunakan penalaran induktif dengan tipe penelitian eksploratif, yaitu mengumpulkan data sebanyak-banyaknya untuk dapat mengidentifikasi dan mengetahui potensi situs serta konteksnya dengan temuan lain dan lingkungannya. Teknik pengumpulan datanya dilakukan melalui survei ke lokasi situs dan lingkungan sekitarnya.

\section{Lingkungan dan Tinggalan Arkeologis}

Situs Borowetan berada pada dataran aluvial yang terbentuk oleh endapan material Sungai Bogowonto yang terletak di sebelah barat situs. Sungai Bogowonto berhulu di utara, yaitu di daerah Temanggung dan bermuara di 
Samudra Indonesia, letaknya di selatan Purworeja. Bagian selatan ini merupakan suatu dataran aluvial pantai dan betinggisik (beachridge) yang memanjang mengikuti garis pantai. Jarak dari Situs Borowetan sampai ke garis pantai sekitar $16 \mathrm{~km}$. Situs yang terdapat di dekat muara Sungai Bogowonto adalah Situs Watukura, yang masuk wilayah Kecamatan Purwodadi.

Di bagian timur dataran aluvial, terdapat perbukitan, yang merupakan bagian dari Pegunungan Menoreh. Sejumlah sungai yang berhulu di Pegunungan Menoreh bertemu dengan Sungai Bogowonto, antara lain Sungai Jogoresan yang bersambungan dengan Kaligesing, Sungai Kodil, dan Sungai Kayulawang. Daerah pegunungan Menoreh memiliki situs arkeologis yaitu Situs Gua Seplawan, jaraknya sekitar $12 \mathrm{~km}$ dari Situs Borowetan, dan Situs Pendem sebagai tempat penemuan prasasti Pendem berangka tahun Saka 803.

Situs Borowetan terletak di wilayah RT 02 RW 04 Desa Borowetan Kecamatan Banyuurip. Sebelumnya Desa Borowetan bernama Desa Borotengah. Penggunaan lahan di desa ini terdiri dari permukiman penduduk, tanah tegalan, dan persawahan. Struktur bata kuna yang ditemukan di tanah pekarangan milik Djojo Sukarto berada di dasar sungai kecil pada kedalaman sekitar 1,5 meter dari permukaan tanah sekarang. Menurut keterangan penduduk, sungai ini tidak diketahui namanya, yang merupakan air buangan dari sungai yang terdapat di Beji, letaknya di sebelah utara Desa Borowetan.

Bata kuna berukuran panjang $30 \mathrm{~cm}$, lebar $19 \mathrm{~cm}$ dan tebal $9,5 \mathrm{~cm}$. Pada waktu peninjauan, sebagian besar bata masih dalam kondisi utuh dan terendam air. Sebagian bata telah lepas dari susunannya yang kemudian dipindahkan ke rumah penduduk.

Melalui pengupasan tanah di lokasi, diketahui adanya struktur bata yang memanjang utara-selatan. Panjang struktur yang tampak sekitar 4 meter. Kedua ujung struktur ini membentuk sudut dan membelok ke arah barat, sehingga terdapat struktur bata yang memanjang barat timur di sisi utara dan selatan. Tidak diketahui panjang kedua sisi tersebut karena terbenam ke dalam dinding tebing sungai, diperkirakan terus berlanjut di dalam tanah pekarangan. Berdasarkan pengecekan langsung di lokasi, struktur bata ini sedikitnya terdiri dari enam lapis bata yang tingginya lebih kurang $60 \mathrm{~cm}$. Lapisan bata paling bawah tidak diketahui karena masih tertutup tanah lempung dan pasir.

Selain struktur bata, temuan lain yang terdapat di wilayah Desa Borowetan adalah lumpang batu, yoni dan lokasi penemuan prasasti Kayu Ara Hiwang. Sebuah lumpang batu terdapat di rumah penduduk, jaraknya sekitar 200 meter di sebelah barat Situs Borowetan. Lumpang ini berbadan bulat tak beraturan dengan permukaan atasnya datar dan terdapat lubang di tengahnya. Ukuran tinggi 
lumpang $42 \mathrm{~cm}$, garis tengah yang terlebar $70 \mathrm{~cm}$, garis tengah lubang $25 \mathrm{~cm}$, dan kedalamannya $20 \mathrm{~cm}$.

Sekitar 400 meter di sebelah barat Situs Borowetan terdapat lokasi penemuan prasasti Kayu Ara Hiwang yang berangka tahun Saka 823 (901 Masehi). Prasasti tersebut sejak tahun 1890 disimpan di Museum Nasional Jakarta, tercatat dengan nomor inventaris D.78. Lokasi penemuan terletak di tepi Sungai Bogowonto, di bawah pohon besar. Saat ini di lokasi tersebut terdapat pohon sono yang tumbuh besar dan tinggi. Di depan pohon berdiri bangunan berupa panggung terbuka yang didirikan oleh Pemerintah Kabupaten Purworeja dalam kaitan prosesi upacara Hari Jadi Kabupaten Purworeja yang menggunakan pertanggalan prasasti Kayu Ara Hiwang (5 Oktober 901 Masehi).

Menurut Radix Penadi (1998), tidak jauh dari lokasi penemuan prasasti Kayu Ara Hiwang terdapat sebuah yoni di tengah sawah, tepatnya di belakang kantor Bina Marga Desa Borowetan. Peninjauan kali ini belum melakukan pengecekan terhadap keberadaan benda purbakala tersebut.

\section{Wilayah Kerakaian Balitung}

Dyah Balitung adalah salah satu raja besar yang bertahta pada masa Kerajaan Mataram Kuna. Walaupun Balitung adalah raja Mataram yang terkenal namun sebenarnya dia bukanlah pewaris tahta yang syah. Menurut Schrieke, raja-raja yang menunjukkan silsilah seperti halnya Airlangga dalam prasasti Pucangan (963 Saka) dan Raden Wijaya dalam prasasti Kudadu (1216 Saka) tidak berhak penuh atas tahta kerajaan (Schrieke, 1975; Nastiti, 1982: 3). Dyah Balitung naik tahta karena perkawinannya dengan anak Rakai Watuhumalang, penguasa sebelumnya. Prasasti Mantyasih menyebutkan bahwa pada saat menikah ia masih bergelar haji atau raja bawahan. Dyah Balitung adalah seorang pangeran dari daerah Kedu Selatan, yaitu dari daerah Watukura (Nastiti, 1982: 3). Menurut Poerbatjaraka, Watukura terletak di tepi Sungai Bogowonto di daerah Purwodadi, Kabupaten Purworejo, Jawa Tengah. Poerbatjaraka juga menafsirkan bahwa seorang raja yang memakai kata dharmma (Rake Watukura Dyah Balitung Sri Dharmmodaya Mahasambhu) adalah raja yang naik tahta karena perkawinan (Poerbatjaraka, 1930: 171-183). Oleh karena itu untuk melegitimasi kedudukannya sebagai raja dia menerbitkan prasasti Mantyasih yang berisi genealogi raja-raja Mataram sejak Sanjaya hingga Balitung.

Salah satu prasasti yang diterbitkan oleh raja Balitung adalah prasasti Watukura berangka tahun 824 Saka (902 M). Prasasti ini kemudian diturunkan kembali (tinulad) di daerah Jawa Timur. Asal temuan prasasti tembaga ini tidak jelas tetapi berkaitan dengan daerah Watukura dekat Bagelen (Kecamatan Purwodadi), Jawa Tengah. Daerah Watukura pada jaman dahulu merupakan daerah lungguh 
(apanage) raja Balitung. Sebagai raja Mataram, Balitung berhasil meluaskan pengaruhnya dan menguasai daerah Jawa Timur (Atmodjo, t.t.: 14-15). Desa Watukura dahulu merupakan sebuah sima dan pernah dipimpin oleh Apanji Kalajaya (Atmodjo, t.t.: 20-21). Saat ini Desa Watukura masih ada, yaitu di tepi Sungai Bogowonto. Di desa ini ditemukan dua buah lumpang batu. Sungai Bogowonto dahulu juga merupakan sungai yang terkenal. Dahulu sungai ini bernama Sungai Watukura, di dalam naskah Bhujangga Manik yang ditulis sekitar akhir abad XV atau awal abad XVI M sungai itu disebut Ci Watukura (Atmodjo, t.t.: 16).

Sebagai daerah watak tentunya Watukura dahulu mempunyai wilayah yang lebih luas dari Desa Watukura sekarang. Di dalam Prasasti Watukura B (1348 M) disebutkan bahwa wilayah Watukura terdiri dari beberapa desa yaitu desa Babadan, Matapanas, Payaman, Buhara Suwul, Buhara Unduh, Buhara Hoya, Buhara Tengah, Buhara Panganten, Bareng, dan Antulan (Atmodjo, t.t.: 21). Banyaknya desa yang masuk wilayah Watukura menunjukkan betapa luasnya wilayah Watukura dahulu.

\section{Borowetan Sebuah Situs Di Wilayah Kerakaian Balitung}

Situs Borowetan tempat ditemukannya struktur bata kuna diperkirakan merupakan situs masa klasik. Situs ini terletak tidak jauh dari lokasi temuan prasasti Kayu Ara Hiwang yang cukup terkenal, khususnya di daerah Purworejo. Prasasti yang ditemukan sekitar tahun 1890 yang kini disimpan di Museum Nasional Jakarta itu berasal dari tahun 901 M, yaitu masa ketika Kerajaan Mataram kuna diperintah oleh raja Balitung. Prasasti itu berisi tentang penetapan Desa Kayu Ara Hiwang menjadi sima, desa yang dibebaskan dari pembayaran pajak untuk kerajaan, karena desa itu diwajibkan untuk memelihara sebuah bangunan suci di desa Pariwutan. Kayu Ara Hiwang dan Pariwutan merupakan desa-desa kuna yang disebutkan dalam prasasti. Disebutkan pula bahwa desa (wanua) Kayu Ara Hiwang ini termasuk dalam wilayah (watak) Watu Tihang. Menurut MM Sukarto K. Atmodjo, Kayu Ara Hiwang saat ini berubah menjadi Kroya-Brengkelan. Desa Kroya di Kecamatan Kemiri merupakan perubahan ucapan Kayu Ara dan Brengkelan (Purworejo) merupakan perubahan dari kata Hiwang yang berarti membantah (Bahasa Jawa: ngengkel/mbrengkel) (Atmodjo, t.t.: 18). Watu Tihang yang merupakan watak dari Desa Kayu Ara Hiwang dapat disamakan dengan desa Salatiang (Kecamatan Lowano). Salatiang merupakan kekeliruan ucapan dari Selatiang (sela berarti batu). Desa Salatiang terletak di pinggir Sungai Bogowonto dan di lokasi tersebut ditemukan menhir (batu tegak menyerupai tiang). Sedangkan Pariwutan tempat bangunan suci (parhyangan) itu berada sekarang menjadi desa Pulutan di Kecamatan Ngombol. Desa Pulutan ternyata berbatasan dengan desa Candi. Desa Candi-Pulutan sama pengertiannya dengan parhyangan i pariwutan (Atmodjo, t.t.: 19). Pariwutan yang kemudian 
berubah menjadi Paliwutan dan akhirnya menjadi Desa Pulutan nampaknya bisa diterima demikian juga Watu Tihang menjadi Salatiang, namun Kayu Ara Hiwang yang berubah menjadi Kroya-Brengkelan sulit diterima. Jika Kayu Ara adalah semacam pohon ficus (beringin, ara) (Atmodjo, t.t.: 18) dan hiwang berarti miring (condong) (Wojowasito, 1973: 324), maka Kayu Ara Hiwang berarti pohon beringin yang miring. Di Kecamatan Bayan, Kabupaten Purworejo ada desa bernama Bringin. Tampaknya desa Bringin ini lebih dekat dengan arti Kayu Ara Hiwang. Di Desa Bringin ditemukan sebuah lumpang batu. Lumpang batu selain berfungsi praktis untuk menumbuk biji-bijian (padi) juga berfungsi religius misalnya untuk upacara penetapan sima.

Situs Borowetan memang baru tersingkap sebagian kecil saja, yang berupa struktur bata sisi timur. Sehingga melalui data yang hanya sedikit tersebut sangat sulit untuk mengungkap latar belakang sejarahnya, khususnya apabila dikaitkan dengan sejarah kerajaan Mataram kuna. Walaupun situs ini terletak dekat dengan ditemukannya prasasti Kayu Ara Hiwang, namun masih sulit juga untuk mengkaitkannya dengan prasasti tersebut. Di dalam prasasti itu memang disebutkan adanya sebuah kompleks bangunan suci (parhyangan) yang harus dirawat oleh penduduk desa Kayu Ara Hiwang. Namun bangunan suci itu terletak di Pariwutan. Jika benar Pariwutan adalah Desa Pulutan sekarang yang berada di Kecamatan Ngombol -- seperti dikatakan oleh MM Sukarto K. Atmodjo -- berarti struktur bata itu bukan bagian dari bangunan suci seperti disebutkan dalam prasasti Kayu Ara Hiwang.

Prasasti yang ditemukan di daerah Purworejo yang juga menyebut adanya sebuah bangunan suci selain prasasti Kayu Ara Hiwang adalah prasasti Watukura. Prasasti Watukura yang berasal dari tahun $902 \mathrm{M}$ itu menyebut dharmma pangastulan yang berarti bangunan suci yang besar. Prasasti ini juga menyebutkan nama-nama desa yang berada di wilayah Watukura. Salah satu desa yang dicatat adalah Desa Buhara Tengah. Nama Desa Buhara Tengah ini mengingatkan pada Desa Boro Tengah -- tempat ditemukannya prasasti Kayu Ara Hiwang -- yang saat ini berubah menjadi Boro Wetan. Bisa jadi Desa Boro Tengah sekarang merupakan perubahan dari Buhara Tengah karena ucapannya yang hampir sama. Prasasti Watukura memang tidak menyebutkan lokasi yang tepat tentang keberadaan bangunan suci itu. Prasasti itu hanya menyebutkan adanya bangunan suci di wilayah Watukura. Jika disebutkan ada beberapa desa yang termasuk wilayah Watukura maka kemungkinan wilayah tersebut cukup luas. Jadi ada kemungkinan bangunan suci itu berada di Desa Buhara Tengah (Boro Tengah). Di Desa Borowetan (dahulu Boro Tengah) telah ditemukan struktur bata kuna. Permasalahannya apakah struktur bata ini adalah bagian dari bangunan suci seperti disebutkan dalam prasasti Watukura? Untuk dapat memecahkan masalah ini perlu dilakukan penelitian yang mendalam. Oleh karena itu, perlu dilakukan ekskavasi di situs Borowetan agar dapat 
menampakungkapkan arsitektur bangunannya. Dengan demikian akan dapat diketahui apakah struktur bangunan itu merupakan bagian dari bangunan suci ataukah bangunan profan. Jika struktur bangunan itu merupakan sebuah kompleks bangunan suci yang cukup besar maka kemungkinan dapat dikaitkan dengan bangunan suci seperti disebutkan dalam prasasti Watukura yang juga merupakan candi raja (dharmma haji).

\section{DAFTAR PUSTAKA}

Atmodjo, M.M. Sukarto K. Atmodjo

t.t. $\quad$ "Identitas Bagelen" dalam kaitannya dengan Masalah Hari Jadi Purworejo, makalah tidak diterbitkan.

Boechari

1977 Epigrafi dan Sejarah Indonesia, Majalah Arkeologi, tahun I No 2. Jakarta: Lembaga Arkeologi Fakultas Sastra Universitas Indonesia, hlm. 1-40.

1981 Ulah Para Pemungut Pajak di dalam Masyarakat Jawa Kuna, Majalah Arkeologi, tahun IV, no. I-2, Fakultas Sastra Universitas Indonesia, hlm. 67-87.

Casparis, J.G de

1956 Selected Inscriptions From7th to The $9^{\text {th }}$ Century AD, Prasasti Indonesia II. Bandung: Masa Baru.

Christie, Jan Wisseman

1989 Raja dan Rama Negara Klasik Awal di Jawa dalam Pusat, Simbol, dan Hirarki Kekuasaan. Jakarta: Yayasan Obor Indonesia.

Dwiyanto, Djoko

1981 Beberapa Masalah Transportasi Di Jawa Tengah Pada Masa Pemerintahan Balitung (tahun 899-910), Skripsi pada Fakultas Sastra dan Kebudayaan Universitas Gadjah Mada. 
Fitriati, Rita

1990 Pasak-pasak Dari Masa Balitung dan Sindok, Monumen, Lembaran Sastra seri penerbitan Ilmiah No. 11 edisi khusus Fakultas Sastra Universitas Indonesia.

Kartakusuma, Richadiana

1994-1995 Tinjauan Kembali Isi Prasasti Poh (827S/907M): Sedikit Catatan Tentang Alasan Pemilihan Suatu Daerah Perdikan, Analisis Sumber Tertulis Masa Klasik. Jakarta: Proyek Penelitian Purbakala Jakarta.

Kusen, nfn. (1994). Raja-raja Mataram Kuna dari Sanjaya Sampai Balitung Sebuah Rekonstruksi Berdasarkan Prasasti Wanua Tengah III. Berkala Arkeologi, 14(2), 82-94.

https://doi.org/10.30883/jba.vl 4i2.721

Nastiti, Titi Surti dkk.

1982 Tiga Prasasti Dari Masa Balitung. Pusat Penelitian Arkeologi Nasional, Jakarta. 